\title{
NEW PARADIGM OF CO-MANAGEMENT OF MPAS IN INDONESIA, LESSONS LEARNED FROM COREMAP
}

\author{
Suraji *, Toni RUCHIMAT *, Sudirman SAAD ** and Sriyanti WIBISANA *** \\ * Ministry of Marine Affairs and Fisheries, Directorate of Aquatic and Marine Resource Conservation \\ suraji_a@yahoo.com, truchimat@yahoo.com \\ ** Ministry of Marine Affairs and Fisheries, Directorate of Aquatic and Marine Resource Conservation, \\ sudirmansaad@yahoo.com \\ *** Ministry of Marine Affairs and Fisheries, Directorate of Aquatic and Marine Resource \\ Conservation, Bappenas, sriyanti@bappenas.go.id
}

DOI: 10.1515/trser-2015-0026

KEYWORDS: co-management, MPAs, COREMAP, Indonesia.

\section{ABSTRACT}

Establishment and Co-management of Marine Protected Areas (MPAs) which are conducted by Coral Reef Rehabilitation and Management Project (COREMAP) Phase II represents a new paradigm from the top-down approach, that being the bottom-up communitybased approach. The process of establishing MPAs initiated by village level has legalized by village regulations on enacting of no-take zones (NTZs). There are five steps and an 18 months period of establishment and management of NTZs. The networks of village level MPAs also is functioning as no-take area of District MPA that is managed by the District Government. With a new paradigm, collaborative management of MPAs is exemplified by COREMAP Phase II through the sharing of responsibility between central and local government as well as community, providing an unique typical feature in the management of conservation areas in Indonesia.

ZUSAMMENFASSUNG: Eine neue Herangehensweise im Co-Management Mariner Schutzgebiete (MPA) in Indonesien, Erkenntnisse aus dem Projekt zur Renaturierung von Korallenriffen.

Etablierung und Co-Management in Marinen Schutzgebieten (Marine Protected Areas/ MPAs), die im Rahmen der zweiten Phase des Korallenriff Renaturierungs- und Managementprojektes (COREMAP) angewendet wurden, stellen eine neue Herangehensweise dar, die nicht von der oberen, sondern von der unteren Ebene, den Kommunen, ausgeht. Der auf Gemeindeebene initiierte Prozess der Etablierung eines Managements von Marinen Schutzgebieten, hat durch einen kommunalen Beschluss die Einrichtung von eingriffsfreien Zonen (NTZ- no-take zones) rechtskräftig gemacht. Für Einrichtung und Management dieser Zonen gibt es einen fünf Stufenplan über einen Zeitraum von 18 Monaten. Das Netzwerk der Marinen Schutzgebiete (MPA) auf kommunaler Ebene, funktioniert ebenfalls in Form eingriffsfreier Mariner Schutzgebiete, deren Management beim Distrikt Gouvernement liegt. Mit einem neuen Paradigma wird das kollaborative Management von Marinen Schutzgebieten (MPAs) durch die Phase II des Korallenriff Renaturierungs- und Management Projekts /COREMAP beispielhaft durch die geteilte Verantwortlichkeit zwischen zentraler und lokaler Regierung sowie den Kommunen dargestellt und liefert ein einmaliges, typisches Merkmal im Management von Schutzgebieten in Indonesien. 
REZUMAT: O nouă abordare în co-managementul Ariilor Marine Protejate din Indonezia, noi cunoştinţe din Proiectul de Reabilitare şi Management al Recifelor coraliere (COREMAP).

Implementarea şi co-managementul Ariilor Marine Protejate (Marine Protected Areas/MPAs), care au fost aplicate în cadrul fazei a II-a a Proiectului de Reabilitare şi Management al Recifelor Coraliere (COREMAP) prezintă o nouă abordare, care nu porneşte de la nivelul superior, ci de la cel inferior, al comunelor. Procesul de implementare a unui management al Ariilor Marine Protejate, iniţiat la nivel comunal, a legiferat printr-o decizie comunală, organizarea de Zone Fără Intervenţii (NTZ no-take zones). Pentru organizarea şi managementul acestor zone, există un plan de realizare în cinci etape pe o perioadă de 18 luni. Rețeaua Zonelor Marine Protejate (MPA) la nivel comunal funcţionează de asemenea, sub formă de zone marine fără intervenţie, responsabilitatea managementului lor fiind la nivelul guvernului districtual. Managementul colaborativ ale Zonelor Marine Protejate se exemplifică prin Faza a II-a a Proiectului de Reabilitare şi Management al Recifelor Coraliere, cu o nouă paradigmă reprezentată prin responsabilitatea împărţită între guvernul central, cel local şi prin comune, furnizând un indicator unic şi tipic în managementul de arii protejate din Indonezia.

\section{INTRODUCTION}

Indonesia is the world's largest archipelagic nation, with 17,480 islands, 95,181 km coastline, $3.1 \mathrm{~km}^{2}$ territorial waters, and $2.7 \mathrm{~km}^{2}$ of Exclusive Economic Zone. The coastal zone is a highly productive ecosystem that serves as an important base for the country's economic growth. Over $55 \%$ of the national fishery harvest comes from capture fisheries in coastal areas. Some of the richest areas of biodiversity are found in the coastal zone of the country, and include coral reefs, mangrove swamps, sea grass beds, lagoons, and estuaries. Indonesia's coastal zone is home to 2,500 species of mollusks, 2,000 species of crustaceans, six species of sea turtles, 30 of marine mammals, over 2,000 of fish, and extensive coral reefs.

As a part of Coral Triangle area, Indonesia has diverse and extensive coral reef with its 70 genera and 500 species of hard corals covering $32,935 \mathrm{~km}^{2}$ or about $16.5 \%$ of the global area of coral reefs. It is considered as the second largest coral reef in the world after Great Barrier Reef in Australia. This coral reef provides a lot of benefits, including coastal protection from storm waves, food sources and habitats of biota, genetic materials for drugs, coral and sand beaches and diving areas for millions of tourists.

Although coral reefs are recognized as one of the most productive ecosystems in the world, they are very susceptible to both natural and human impacts. Coral reefs are declining in many areas due to steadily increasing threats from direct human pressures and indirect effects of global climate change. Human pressures or anthropogenic stress is much more dangerous for coral reefs because it is not only permanent but has also the tendency to increase within a period of time (Sorokin, 1993). Human stressors or anthropogenic stress in South East Asia region has the highest rate compared with other regions such as Micronesia, Polynesia, GBR Australia, Hawaii, Red Sea, East Pacific, and West Atlantic (Sorokin, 1993).

In Indonesian coral reefs in particular, there are six categories of negative anthropogenic impact that may be commonly encountered (Nontji, 2002): (1) siltation as an effect from land clearing and deforestation which resulted in land erosion and runoff; (2) pollution in the river coming from industrial waste, urban development, and agricultural waste; (3) coral and sand mining for building material; (4) dredging, filling, and coastal construction activities causing negative impact by covering the reefs with sediment; (5) destructive fishing such as blasting and use of cyanide which have been widely practiced even in remote islands or National Parks; (6) extensive development of marine tourism without proper management. 
Series monitoring data showed that there was significant improvement in the condition of coral reef between 1998 and 2007. In 2007, only 6.4\% of the coral reef of Indonesia was in excellent condition, while the rest $24.3 \%$ was good, $29.2 \%$ was poor, and $40.1 \%$ was damaged. In addition, in 2007 excellent coral reef has decreased to 5.5\%, good 25.1\%, poor $37.3 \%$, and damaged 32.1\% (Lipi, 2007).

\section{RESULTS AND DISCUSSION}

\section{Marine Protected Area, Indonesia context}

In response to the coastal and marine resources degradation, Government of Indonesia collaborates with other institutions safeguarding coral reef and its associate ecosystems through establishing Marine Protected Area (MPA), as it is believed as the best tool to manage fisheries resources in sustainable fashion. MPA is defined as a water area, which is protected and managed through zoning system, to achieve sustainable management of fish resources and its environment. In fact Indonesia has long experiences in conserving natural resources, marine resources protection program entering new paradigm since Law 31/2004 and Law 45/2009 on fisheries formalized and Government Regulation (PP) No. 60/2007 on Fisheries Resources Conservation signed. Before these policies were enacted, perspective to the conservation program was mostly focused on protection and preservation. These programs lead to conflict among communities and also of the community against government policies.

Based on the new policies, approach in the planning and management of MPA shifted from centralized to the decentralised approach in line with local autonomy. Government encouraged local government in the provincial, district and village levels to develop and manage their own MPAs. Focus of conservation program now is not only to protect marine biodiversity rather than the multipurpose MPA while empowering local community. Shifting paradigm of the conservation program in Indonesia could be revealed based on table 1.

Table 1: Shifting paradigm on MPA planning and management in Indonesia.

\begin{tabular}{|c|c|c|c|c|c|}
\hline Aspect & \multicolumn{2}{|c|}{ Past } & \multicolumn{2}{|c|}{ Present } & Note(s) \\
\hline & Central & Local & Central & Local & \\
\hline Initiative & $\mathrm{V}$ & $\mathrm{X}$ & $\mathrm{V}$ & $\mathrm{V}$ & \\
\hline Management & $\mathrm{V}$ & $\mathrm{X}$ & $\mathrm{V}$ & $\mathrm{V}$ & $\begin{array}{c}\text { Open to } \\
\text { develop co- } \\
\text { management }\end{array}$ \\
\hline Evaluation & $\mathrm{V}$ & $\mathrm{X}$ & $\mathrm{V}$ & $\mathrm{V}$ & \\
\hline Biodiversity protection & \multicolumn{2}{|c|}{ YES } & \multicolumn{2}{|c|}{ Yes } & \\
\hline Sustainable fisheries & \multicolumn{2}{|c|}{ Limited } & \multicolumn{2}{|c|}{ Yes } & \\
\hline Sustainable tourism & \multirow{2}{*}{\multicolumn{2}{|c|}{$\frac{\text { Limited }}{\text { Limited }}$}} & \multirow{2}{*}{\multicolumn{2}{|c|}{$\begin{array}{l}\text { Yes } \\
\text { Yes }\end{array}$}} & \\
\hline Community empowerment & & & & & \\
\hline Policies & \multicolumn{2}{|c|}{ Mix terrestrial and } & \multicolumn{2}{|c|}{ ed coastal } & $\begin{array}{l}\text { MPA using } \\
\text { own policies }\end{array}$ \\
\hline
\end{tabular}

According to the Law 31/2004 and Law 45/2009 and PP no. 60/2007, MPAs in Indonesia are divided into four categories namely marine national park, marine tourism park, fisheries reserve, and marine nature reserve. In addition, there are also coastal and small island parks, and coastal and small island reserves as other conservation areas category cited in the Law 27/2007 on Coastal Zone and Small Island Management. 
Marine national park is the only conservation area initiated and managed by national policy, while the others could be initiated and managed by national, local government or collaboration among them. In addition, refer to the IUCN category marine national park is correspond to the category II, marine tourism park fits with category V, and marine nature reserve and fisheries reserve are matches with category IV of IUCN. Objectives, management, and main focus of each MPA category are described in table 2.

Table 2: Category of MPA in Indonesia.

\begin{tabular}{|l|l|l|l|c|}
\hline \multicolumn{1}{|c|}{ Name } & \multicolumn{1}{|c|}{ Objective } & Management & \multicolumn{1}{c|}{ Main focus } & IUCN \\
\hline $\begin{array}{l}\text { Marine } \\
\text { National } \\
\text { Park }\end{array}$ & $\begin{array}{l}\text { Science, research, education, } \\
\text { sustainable fisheries, tourism, } \\
\text { recreation }\end{array}$ & National & $\begin{array}{l}\text { 1. Biodiversity } \\
\text { 2. Tourism } \\
\text { 3. Fisheries }\end{array}$ & II \\
\hline $\begin{array}{l}\text { Marine } \\
\text { Tourism Pak }\end{array}$ & Tourism and recreation & National/local & $\begin{array}{l}\text { 1. Tourism } \\
\text { 2. Biodiversity }\end{array}$ & V \\
\hline $\begin{array}{l}\text { Marine } \\
\text { Nature } \\
\text { Reserve }\end{array}$ & $\begin{array}{l}\text { To protect fisheries } \\
\text { biodiversity and its } \\
\text { ecosystems }\end{array}$ & National/local & $\begin{array}{l}\text { Fish diversity } \\
\text { and its } \\
\text { ecosystem }\end{array}$ & IV \\
\hline $\begin{array}{l}\text { Fisheries } \\
\text { Reserve }\end{array}$ & To protect certain species & National/local & $\begin{array}{l}\text { Protection of } \\
\text { certain species }\end{array}$ & IV \\
\hline
\end{tabular}

Furthermore, regarding the zoning system, all the MPA should have core zone at least $2 \%$ of total area. Zoning of the MPA consists of core zone, sustainable fisheries zone, utilization zone, and other zone. Core zone is designed to focus on biodiversity protection, while other zones are to support sustainable activities such as fisheries and or marine ecotourism. Regulations related to each zone are presented in table 3.

Table 3: Activities at each zone of MPA.

\begin{tabular}{|l|c|c|c|c|}
\hline \multicolumn{1}{|c|}{ Activity/Zone } & Core & Sust. fisheries & Use & Other \\
\hline Research and monitoring & yes & yes & yes & yes \\
\hline Education & yes & yes & yes & no \\
\hline Fisheries, selected gears & no & yes & no & no \\
\hline Mariculture & no & yes & no & no \\
\hline Marine eco-tourism & no & yes & yes & no \\
\hline Basic infrastructures development & no & yes & yes & yes \\
\hline
\end{tabular}

\section{COREMAP II}

Coral reef Rehabilitation and Management Project (COREMAP) is a long term commitment of the Government of Indonesia to better manage coral reef ecosystems. Started through COREMAP phase I during 1999-2003 as initiation step, COREMAP phase II as acceleration step is designed to establish a management system for coral reef resources in priority areas. It has been implemented since 2004 under Ministry of Marine Affair and Fisheries. COREMAP II aims to protect, rehabilitate, and achieve sustainable use of the Indonesian coral reefs and their associated ecosystems which, in turn, enhance the welfare of the coastal communities. Main objectives of the program are to: 1) strengthen institutional capacity to manage coral reef resources at the national and local levels; 2) preserve and rehabilitate coral reef resources by empowering community groups to actively involvement in every step of management cycle; 3) increase public awareness and knowledge of local community on the sustainable management of coral reefs. 
The COREMAP II is implemented through Ministry of Marine Affairs and Fisheries and funded by the Asian Development Bank for the western part of Indonesia and by the World Bank for eastern part of Indonesia. The program covers eight provinces and 15 districts: 1) North Sumatera Province (districts of Nias, South Nias, and Central Tapanuli); 2) West Sumatera (Mentawai); 3) Riau Islands (Batam, Bintan, and Natuna); 4) South Sulawesi (Pangkep and Selayar); 5) Southeast Sulawesi (Buton and Wakatobi); 6) East Nusa Tenggara (Sikka), 7) Papua (Biak); and 8) West Papua (Raja Ampat). There are three component programs implemented which are institutional strengthening, community based and collaborative management, and public awareness and education.

In terms of institutional strengthening, COREMAP II had developed a policy and a national strategy at national and local levels, development of human resources, project management, program coordination, and legal assistance. Community-based management focused on community empowerment, community-based coral reef management, local MPA management, supports the Marine National Park development, alternative livelihoods development, and local infrastructures. In addition, component of public awareness and education supported public awareness campaign, dissemination of information and education, sea partnership, and program support of communication.

A few project out comes to date include a contribution of about $25 \%$ to the National MPAs as targeted 10 million ha by 2010 and 20 million ha by 2020, supporting the new paradigm of MPA's establishment in Indonesia as a bottom-up process. This has resulted in significant changes of perspective and awareness of the local community, which share budget and responsibilities for the success of the project activities.

\section{Community-based and Co-Management Approach}

Community-based and co-management component provides significant input to the success of the project. Local communities are encouraged to participate in the project activities since the beginning. Community facilitator and village motivator worked together with community in developing village-based MPA, well-known as marine sanctuary or Daerah Perlindungan Laut (DPL) and formalized through village regulation. In addition to the establishment of DPL, head of the village also assigned village leaders as DPL management board, who take responsibility to manage the DPL based on DPL management plan.

There are five steps in establishing the community-based marine sanctuary, starting with socialization until signation of the village ordinance. The first step is the introduction and the socialization of the need and importance conservation program, the gathering of baseline information and delivering the key information of the village which could be carried out in one-six months. After that, it is needed about two-four months to improve the community capacity through community meetings, trainings, information sharing, and cross visits, then conducting public consultations three-six months, drafting village regulation and the approval about three-six months. Finally, after approval of the village regulation, DPL management board will implement the management of DPL which needs additional six-18 months.

In order to scale up these village MPAs to the district level, project management unit and project implementing unit (PIU) assisted by district consultants (WB) and regional advisers (ADB) conduct program synchronizations. District-based MPA, in parallel, will accommodate the villages MPAs as core zones or utilization zones. In the national level, national coordinator unit (WB) or project management office (PMO) assisted by consultants support local government to have MPAs enactment through minister decree. This scaling up processes could be drawn as in figure 1 . 


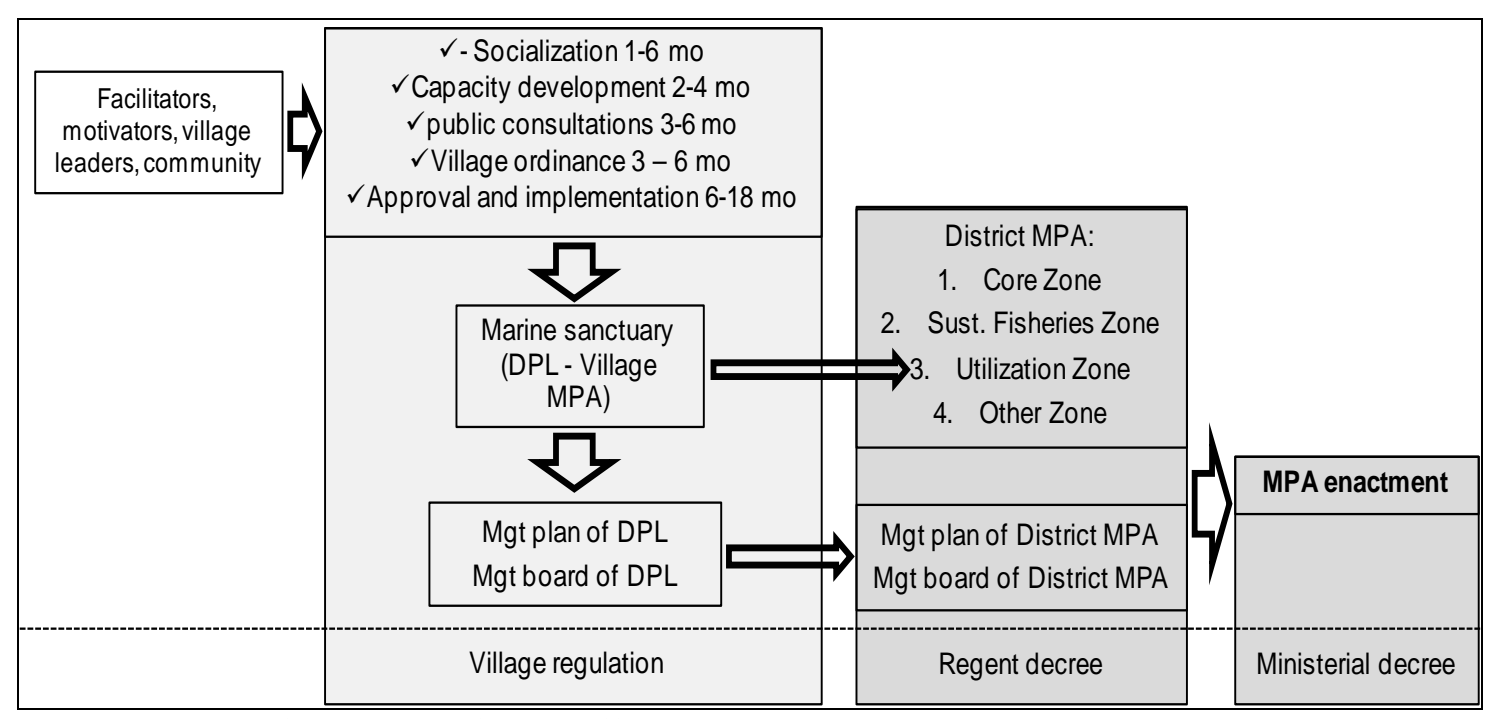

Figure 1: Scaling up village MPA and co-management process.

\section{Challenges and lessons learned}

Indonesia has a long experience in the development of community-based and comanagement of the conservation areas executed by government, non-government organizations, international projects, and events by local community groups. However, through COREMAP II some challenges could be emphasized:

- difficulties in reaching agreements among communities due to different perception levels of conservation concepts and issues;

- long time needed for various meetings at different levels from grass-roots and the need for facilitation from the national/provincial level;

- lack of understanding of marine conservation issues by the local government and community leaders;

- sectoral interest in government officers makes it difficult for program integration and project coordination.

The lessons learnt from the implementation of COREMAP II are:

1. creating the public trust in community-engagement is important as early as the beginning of the program in order for the community to be well informed about the program objectives and become interested to participate in all program activities, this can shorten the duration of the MPA's establishment process;

2. generating self-enthusiasm through institutional strengthening in communities is essential in order to manage the marine conservation area autonomously even after the end of the project;

3. positioning the role of communities as a partner in all activities and to obtain their viewpoints which need to be integrated in program management;

4. local wisdoms on management of marine resources which already exist in communities are important to be appreciated and strengthened through village regulations. 


\section{CONCLUSIONS}

COREMAP program in Indonesia is a unique program because of wide geographic coverage, nationally coordinated but decentralized in implementations, multi-stakeholder inclusion, direct quantifiable fisheries benefit, and sound financial management. The process required the institutional strengthening of communities as well as local governments so that MPAs can be managed sustainably.

COREMAP I and II helped build a strong basis for policies and regulations to manage national coral reef programs, in the form of Strategic Plan and Government Regulation (national and local levels). The program has significantly contributed to sustainable management and utilization of coral reefs, strengthening community awareness and income generation. Besides, COREMAP provided significant benefit in increasing public awareness and reduced rate of coral reefs degradation.

The COREMAP's contributions in the establishment of MPAs are significant for MPAs' national objectives.

The new paradigm, in line with the emerging perspective on marine issues, has strengthened the local wisdom and values of marine resource utilization, as well as increased the sense of belonging in the management of marine resources in a sustainable manner at local community level (grass-roots) and local/regional governments. Collaborative management of MPAs exemplified by COREMAP through the shared responsibility between central and local government, provides a unique perspective, typical for the management of conservation areas in Indonesia. The final objectives of the management targeted by MPAs are sustainable fisheries and community prosperities. 


\section{REFERENCES}

1. Nontji A., 2002 - Coral reefs of Indonesia: past, present and future, Proceeding 9th International Coral Reef Symposium, Bali, Indonesia, 23-27 October 2002, 1, 17-27.

2. Sorokin Y. I., 1993 - Coral Reef Ecology, Springer-Verlag Berlin Heidelberg, Germany.

3. COREMAP. Coral Reef Rehabilitation and Management Program - Phase II, www.coremap.or.id; www.coremap-2.com

4. Suraji Kawasan Konservasi Perairan: Paradigma dan Perkembangannya, http://surajis.multiply.com (in Indonesian) 